\title{
Laboratory Handling of Didymosphenia geminata (Lyngbye) Schmidt and the Effect of Control Efforts on Viability
}

\author{
Jorge Parodi ${ }^{*}$, Pamela Olivares ${ }^{1 *}$, Viviana Chavez ${ }^{2}$, Matías Peredo-Parada3,4 \\ ${ }^{1}$ Laboratorio Fisiología de la Reproducción, Escuela de Medicina Veterinaria, Núcleo de Investigaciónen \\ Producción Alimentaria, Facultad de Recursos Naturales, Universidad Católica de Temuco, Temuco, Chile \\ ${ }^{2}$ Laboratorio de Investigación y Educación Tonalli Ltda, Temuco, Chile \\ ${ }^{3}$ Departamento de Ingenieríaen Obras Civiles, Universidad de Santiago de Chile, Santiago, Chile \\ ${ }^{4}$ Plataforma de Investigaciónen Ecohidrología y Ecohidráulica, EcoHyd Ltda, Santiago, Chile \\ Email: jparodi@uct.cl
}

Received 24 July 2015; accepted 9 August 2015; published 12 August 2015

Copyright (C) 2015 by authors and Scientific Research Publishing Inc.

This work is licensed under the Creative Commons Attribution International License (CC BY). http://creativecommons.org/licenses/by/4.0/

c) (i)

\section{Abstract}

Didymosphenia geminata (Lyngbye) Schmidt is a type of diatom that exists in Chile as an introduced species, invading the country and its rivers. We collected samples of $D$. geminata from two sampling points in Chile, assessing their viability and response to control agents. Fresh $\mathrm{D}$. geminata showed more than $\mathbf{9 0 \%}$ of viable granular forms (containing granules in their cytoplasm); however, the dry form presents near $50 \%$ viability. By creating dry $D$. geminata through exposure to $38^{\circ} \mathrm{C}$ temperatures for 7 days, viability values of the granular form decreased to $20 \%$. D. geminata kept at room temperature for more than 4 weeks reported values of granular forms at $50 \%$, while samples that were refrigerated at $4^{\circ} \mathrm{C}$ maintained values of granular forms at $90 \%$ for 4 weeks. Previous studies suggest that high salt concentration affects the viability of $D$. geminata. When taking wet $D$. geminata samples and exposing them to a solution of $10 \% \mathrm{NaCl}$ for 10 minutes, we observed no differences compared to the control samples, finding granular forms at $\mathbf{9 0 \%}$. When the D. geminata was exposed to a $5 \%$ soap solution, reductions of over $90 \%$ of the granular forms were observed. Our results suggest that the viability of $D$. geminata is associated with the granular content within their cytoplasm, and that it is possible to alter laboratory conditions for their study. These early studies are important in order to better manipulate the model in the laboratory, allowing us to obtain new evidence regarding the microalgae's biology through in vitro studies.

\footnotetext{
${ }^{*}$ Both authors collaborate in equal way.
}

How to cite this paper: Parodi, J., Olivares, P., Chavez, V. and Peredo-Parada, M. (2015) Laboratory Handling of Didymosphenia geminata (Lyngbye) Schmidt and the Effect of Control Efforts on Viability. Advances in Bioscience and Biotechnology, 6, 508-516. http://dx.doi.org/10.4236/abb.2015.68053 


\section{Keywords}

\section{Plague, Viability, Laboratory, Didymo}

\section{Introduction}

Known as "didymo”, Didymosphenia geminata was reported by Rivera et al. (2013) [1] as present in the waters of the rivers of southern Chile. The microalgae are considered a pest in freshwater sources, and as a result control measures have been generated and implemented to prevent its expansion. From an environmental and social perspective, D. geminata may cause changes in the aquatic ecosystem [2] [3] and have negative impacts. Also, this invasive exotic alga generates economic problems for the tourism sector [4]. Its presence in aquatic ecosystems causes a loss of the ecological condition and a decrease in economic resources as a result of increased security measures being implemented and their effects on the landscape [4] [5]. D. geminata uses a great mass of stalks to adhere to the substrates of rivers, streams, and even lakes [6]. The species is an environmental problem that has led to the implementation of various strategies-without positive results - to control the microalgae in Chile and the rest of the world [7] [8]. In Chile, preliminary studies indicate that some rivers such as the Futaleufú, Biobío, and Puelo, are affected by D. geminata, and have implemented imported technology for control measures [4]. Studies indicate that D. geminata alters the microenvironment and reduces the fish population [9]. Furthermore, it reduces the aquatic macro-invertebrate communities and can block the filter systems used for the production of drinking water [10]-[12], and recently reports show that the D. geminata alters the normal function of salmon spermatozoa [13]. In Chile, there are no studies to confirm this, and the full effects that D. geminata has on the microflora and fish are unknown [1]. Laboratory research must be developed that replicates the conditions observed in the field, in order to understand the biology of the microalgae and test protocols for their control.

In Chile such studies have not yet been planned or carried out. Recently, a diagnosis of contaminated rivers was performed to determine factors that created conditions for D. geminata growth. Consequently, the handling of the microalgae in the laboratory is still incipient. We measured the mortality of D. geminata under different treatments commonly used for prevention or control, in order to propose a working model for D. geminata in the laboratory, which considered control measures that could be implemented in the field.

\section{Methods}

\subsection{D. geminata Sample Collection}

D. geminata was collected in the Futaleufú and Biobío rivers during the winter and spring of 2013. Samples were transported to the laboratory in plastic boxes, enclosed in darkness at $10^{\circ} \mathrm{C}$. River water and colonized substrate was also collected for the microalgae.

\subsection{Protocol for the Maintenance of $D$. geminata Samples}

Samples collected were kept in aquariums for laboratory observation. The $D$. geminata contaminated rocks were dispersed in the aquariums, where $50 \%$ of the original river water and $50 \%$ distilled water (total volume of 14 liters) was added, making sure to leave a water column of $15 \mathrm{~cm}$ over them. The aquariums were maintained with insulated expanded polystyrene covers, reducing the temperature to an average of $12^{\circ} \mathrm{C}$ by using a cooling gel system. Water flow was kept constant using a 71,009 model Plaset-Italy $30 \mathrm{~W}$ power engine, and aeration. Macroscopic and microscopic changes in the aquarium with D. geminata were recorded daily as previous report [13].

\subsection{D. geminata Mortality Studies}

The mortality of D. geminata was observed by visual inspection with bright field microscopy, using an inverted Meijie (VT series, Techno Co. Ltd., Japan) microscope to observe the presence or absence of granules within the cytoplasm, denominating them as granular forms [14]. The number of D. geminata cells at $40 \times$ was counted, and the percentage of those that contained granules within the cytoplasm, indicating a viable form, was recorded. In order to improve the documentation with images, Nomarsky microscopy in a $40 \times$ objective (Olympus) was used 
for observation of intracellular structures, and was compared to the viability obtained using modified neutral red staining. To do this, samples were left 10 minutes in a neutral red solution $0.01 \%$ as a way to assess the viability of D. geminata. When a granular red coloration is observed, it indicates a viable form of D. geminata [15].

\subsection{Treatments for Assessing D. geminata Mortality}

Mortality was defined as: The percentage of $D$. geminata cells that were identified as unviable, as they did not present intracellular granules. Each sample, subjected to different treatments, and depending on the increase in non-granular forms, was assessed for its viability and compared to a control sample (untreated, fresh). Percent mortality was determined for each treatment. Fresh samples correspond to the samples collected from the aforementioned rivers, or the samples that were maintained in the laboratory for 2 months without being subjected to any treatment. D. geminata samples were subjected to 7 treatments in order to evaluate their efficiency on the mortality of the microalgae. These treatments included: dehydration or drying of D. geminata under ambient conditions; survival in seawater; treatment by acid digestion; and proposed biosafety treatments in New Zealand and Chile. Treatments with “didymo” are the following: 1) Dry; Dry samples from the sample of polluted rivers. Samples were subsequently hydrated as follows: 10 to 20 grams of algae in 50 ml of sterile distilled water. The samples were dried at room temperature and at $38^{\circ} \mathrm{C}$. 2) Saline solution; $\mathrm{NaCl}$ concentrations between $1 \%$ and 25\%. 3) Soap solutions; concentrations of 1\% to 20\%. 4) Sodium Hypochlorite; concentrations from $1 \%$ to $50 \%$. 5) Natural seawater. 6) Acid; this standard treatment to prepare microalgae samples for electron microscopy involves exposing the samples to 2 or $3 \mathrm{ml}$ of sulfuric acid for 35 minutes, then centrifuging them for $3 \mathrm{~min}$ at $4000 \mathrm{rpm}$. Afterwards, the supernatant is discarded and then $15 \mathrm{ml}$ of distilled water is added. The sample is subsequently centrifuged for $3 \mathrm{~min}$ at $4000 \mathrm{rpm}$, repeating this wash 3 times before the samples are digested with acid. 7) Variation of temperature; microalgae samples were frozen at $-20^{\circ} \mathrm{C}$ for $1 \mathrm{hr}$. and then thawed to observe the number of granular forms. Furthermore, they were exposed to high temperatures, using a solution of river water heated to $45^{\circ} \mathrm{C}$, in which the microalgae were left for 30 minutes and then be observed under the microscope.

Finally, all treatments were subjected to visual inspection viability testing by light microscopy, Nomarsky, or neutral red staining, where the percentage of viable cells was obtained by observing the number of granular and non-granular forms in 10 different fields.

\subsection{Statistical Analysis}

The results are presented as the mean \pm standard error of the mean (SEM). ANOVA analysis was performed, comparing all the observations. A post-test was applied, and the Bonferroni test was used for separation of means with $p<0.05$. Levels of probability $(p)$ less than 0.05 were considered statistically significant. All data was analyzed with the Prism 4.0 statistical program.

\section{Results}

\subsection{Evaluation of Viability Using Intracellular Granules of D. geminata}

We evaluated if the presence of granular forms in D. geminata was an indicator of viability. We compared the percentage of granular forms observed in a fresh sample using visual inspection. With a positive reaction for neutral red, we obtained similar rates for each procedure, 91\% and 93\%, respectively (Figure 1(a)). A similar situation occurs when the samples were dried at $38^{\circ} \mathrm{C}$ for $48 \mathrm{hrs}$. We obtained viability percentages equal to $76 \%$ by visual inspection, and $73 \%$ by the stain "neutral red". The results suggest that use of the number of granules in $D$. geminatais a good indicator of viability.

\section{Mortality of $D$. geminata}

We evaluated the effect of drying on the mortality of D. geminata. In Figure $1(\mathbf{b})$, the variation of viability is shown in time, when the microalgae is dried at room temperature in the laboratory. The mortality samples dried at room temperature for 60 days showed a significant decline from day 15 (Figure 1(b)), reaching values of $41 \% \pm 3 \%$. In a constant temperature model in the laboratory we evaluated the mortality of $D$. geminata. In Figure 1(c), the photomicrograph of the drying conditions is shown, at room temperature for 4 weeks, or $38^{\circ} \mathrm{C}$ for 7 days. In Figure $1(d)$, the graph quantifying for viability under the conditions described 


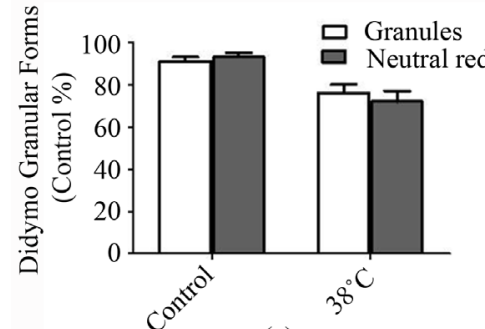

(a)

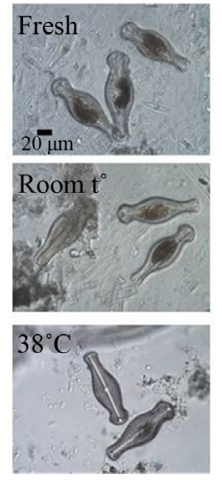

(c)

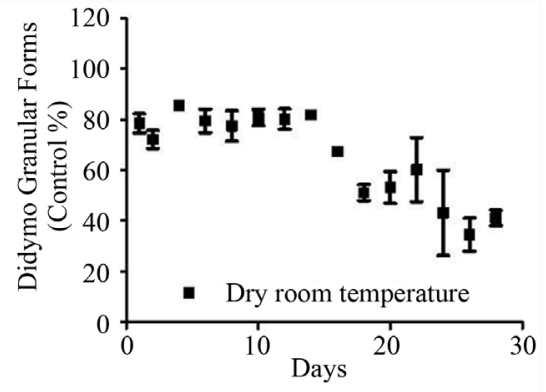

(b)

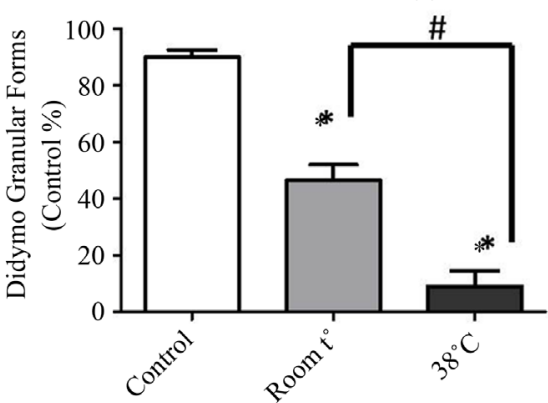

(d)

Figure 1. Maintained Didymosphenia geminata. (a) Comparison of neutral red staining and the observation of granular forms in fresh and $38^{\circ} \mathrm{C}$ conditions; (b) Daily variation chart of dried $D$. geminata granular forms at room temperature; (c) Micrographs of $D$. geminata treated by drying. (d) Quantification of granular forms in drying conditions. The photomicrographs are representative of 5 independent observations. Each bars represents (mean \pm SEM) the measurement of at least 5 independent experiments. The asterisk indicates $p<0.05$ (ANOVA).

is shown, with an increase in mortality of $D$. geminata with values of $90 \% \pm 5 \%$, when the microalgae is dried at $38^{\circ} \mathrm{C}$ for 7 days. The results of this treatment affirm the feasibility of quantifying death by counting granular forms, and the effect of physical treatment, such as drying, in D. geminata viability.

\subsection{The Effect of Drying on D. geminata Mortality}

Contaminated rivers present dried forms of the microalgae on their banks, which are usually described as dead microalgae. Hydration of these samples in the laboratory allowed us to observe that the number of granular forms is similar to the fresh samples handled in the laboratory, as demonstrated in the photomicrographs of Figure 2(a) and Figure 2(b). This suggests that the dry material found on the banks of rivers is a potential pollutant. As a positive control for mortality, fresh samples were subjected to acid digestion, an effective method used to increase the mortality of D. geminata cells. Figure 2(c) shows the quantification of granular forms of samples that were acid-treated, fresh, or dried for 2 months and rehydrated. Acid treated samples showed $97 \% \pm$ $1 \%$ mortality. In samples of fresh $D$. geminata granular forms presented at above $50 \%$, and in the dry samples they presented at $58 \% \pm 5 \%$. These results suggest that drying of the material is not a highly effective control measure, even though it shows a significant change in the level of D. geminata mortality.

\subsection{Effect of Laboratory Control Measures in D. geminata Mortality}

The effects of salinity, surface tension, and change in the temperature have been used to decrease the viability of D. geminata. In our study, under the effect of $10 \% \mathrm{NaCl}$, we observed that at 30 minutes and 24 hours microalgae show a significant mortality, as shown in Figure 3(a). Figure 3(b) shows the effect of increasing concentrations of $\mathrm{NaCl}$, where solutions at $25 \% \mathrm{~m} / \mathrm{v}$ reduce the viability of the samples to $34 \% \pm 2.3 \%$. Figure 3 (c) shows the quantification of the effect of $10 \% \mathrm{NaCl}$ solution when used for 30 minutes or 24 hours, demonstrating that only the 24 -hour treatment is effective in increasing the mortality to $88 \% \pm 2 \%$, but it does not reach 


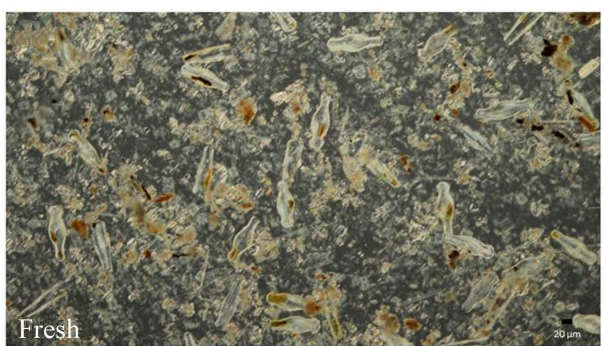

(a)

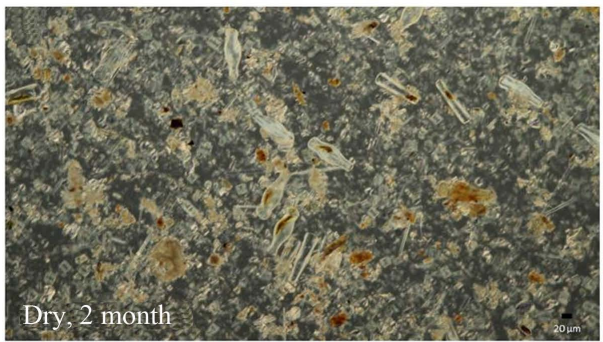

(b)

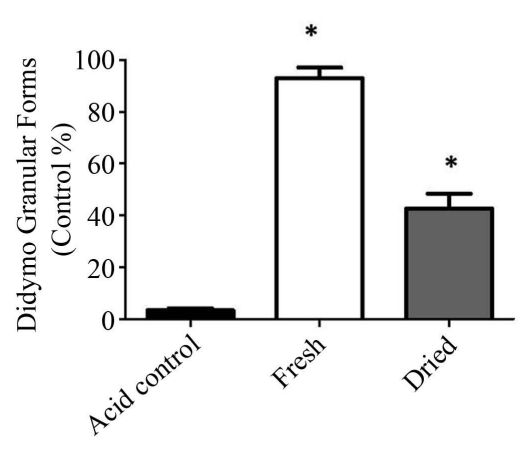

(c)

Figure 2. Hydration of Didymosphenia geminata. (a) Photomicrograph of fresh D. geminata maintained in an aquarium; (b) Photomicrograph of dry D. geminata hydrated in the laboratory; (c) Graph of the presence of granular forms under the conditions indicated above. Photomicrographs are representative of 5 independent experiments. Each bars represents (mean \pm SEM) the measurement of at least 5 independent experiments. The asterisk indicates $p<0.05$ (ANOVA).
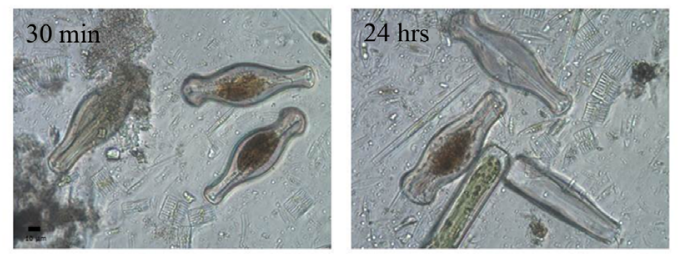

(a)

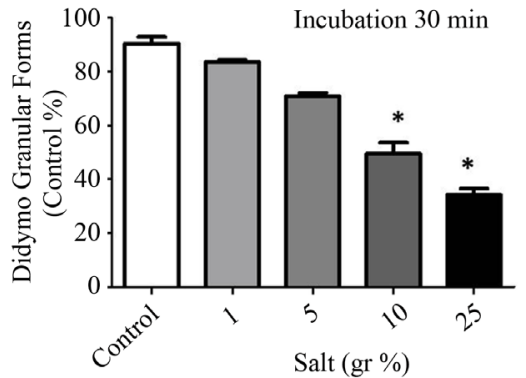

(b)

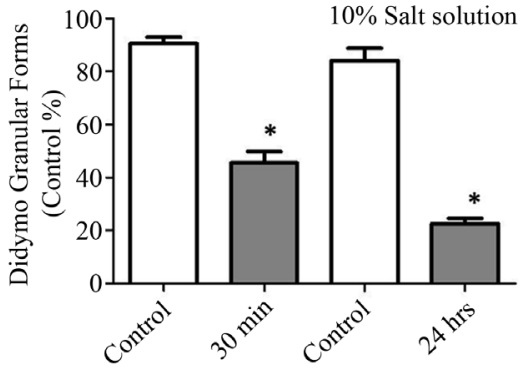

(c)

Figure 3. Effect of $\mathrm{NaCl}$ on D. geminata mortality. (a) Photomicrographs of D. geminata exposed $10 \% \mathrm{NaCl}$ solution; (b) Curve of increasing $\mathrm{NaCl}$ concentrations; (c) Graph quantifying the effect of a $10 \% \mathrm{NaCl}$ solution in time. Photomicrographs are representative of 5 independent experiments. Each bars represents (mean \pm SEM) the measurement of at least 5 independent experiments. The asterisk indicates $p<0.05$ (ANOVA).

$100 \%$ mortality. These results suggest that the use of $\mathrm{NaCl}$ solutions is not effective in eliminating viable $D$. geminata cells in the laboratory. The use of other control measures described in research literature was also evaluated such as: Freezing, high temperatures, seawater, and soap solutions, to eliminate and/or control D. geminata. In Figure 4(b), the quantification of mortality as a result of diverse biosecurity protocols used in different countries is shown. Treatments with salt or freezing are not efficient in eliminating the viability. However, the use of a $5 \%$ soap solution (soap, $5 \mathrm{~min}$ ) was able to increase mortality of $D$. geminata cells up to a rate of $99 \% \pm$ 

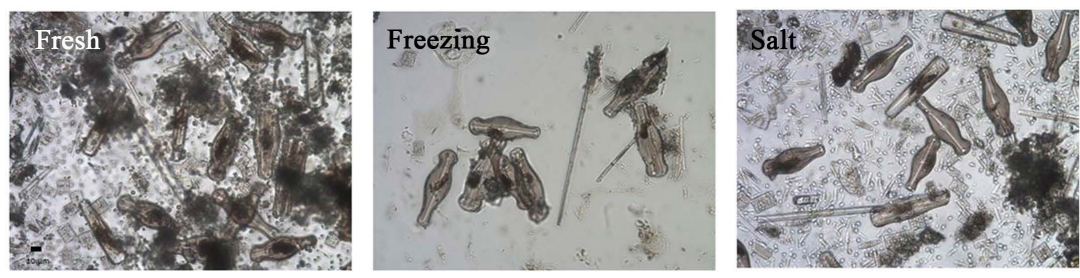

(a)

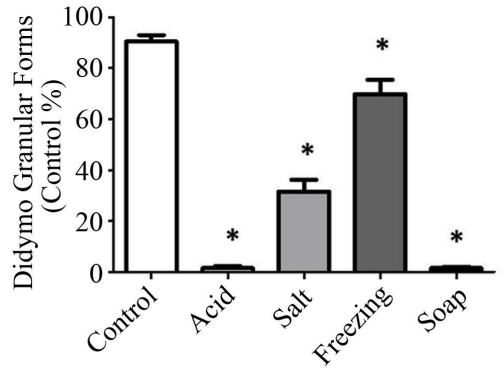

(b)

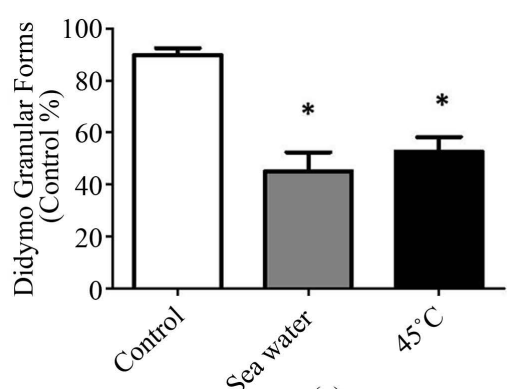

(c)

Figure 4. Other barrier methods. (a) Photomicrographs of fresh, frozen, and NaCl-treated D. geminata; (b) Graph of the diverse treatments that demonstrate D. geminata mortality; (c) Graph of unconventional treatments and their effect on D. geminata mortality. Photomicrographs are representative of 5 independent experiments. Each bars represents (mean \pm SEM) the measurement of at least 5 independent experiments. The asterisk indicates $p<$ 0.05 (ANOVA).

$0.6 \%$. Figure 4(c) shows the effect of seawater (for $30 \mathrm{~min}$ ) and the subjection of algae to temperatures $45^{\circ} \mathrm{C}$ (for $30 \mathrm{~min}$ ). The mortality of $D$. geminata cells reaches values close to $50 \%$ in both treatments. These results suggest that the use of soap solutions are effective in reducing the number of $D$. geminata granular forms, and are a good laboratory control measure.

\subsection{Comparison of Sodium Hypochlorite and Soap Solutions in D. geminata Mortality}

The mortality of D. geminata cells subjected to sodium hypochlorite is shown in Figure 5(a). We observed a decrease in the number of granular forms when compared to the fresh sample that was subjected to soap solutions. Figure 5(b) shows the effect of increasing concentrations of chlorine and soap solutions, where the soap, at a lower concentration (10\%), increases D. geminata cell mortality, reaching $88 \% \pm 5 \%$, compared to the same concentration of chlorine, which achieves $60 \% \pm 3 \%$. Chlorine achieved similar values at concentrations of $20 \%$ solution: $78 \% \pm 5 \%$. The findings of these experiments suggest that the use of sodium hypochlorite is effective in controlling the viability of $D$. geminata, but is less efficient than soap solutions.

\section{Discussion}

D. geminata has been studied for more than 20 years, and its problems are still present in several countries; especially in South America and New Zealand [16]. The results of this study suggest some control mechanisms for the handling of D. geminata in the laboratory, allowing us to establish the groundwork of protocols that will permit in vitro studies to be performed safely, therefore preventing the microalgae from spreading. Recently, a microculture model showed successful results; however, it has not been described as maintaining D. geminata or replicating the conditions of rivers, for studying their development [17]. Previous studies indicated that it is not possible to cultivate $D$. geminata, only to keep it viable for short periods of time, even when varying light or water quality conditions [6]. However, it is possible to preserve D. geminata when alive for diagnosis [18], and even move them in live or granular forms to collection sites before they are transported for analysis and study [19]. Yet, the description to keep them viable in an aquarium-type system is novel in this work, allowing laboratory studies to be done on the microalgae to understand their basic biology [13]. These observations indicate that it is possible to maintain D. geminata in the laboratory for a long time. Furthermore, and contradicting what 


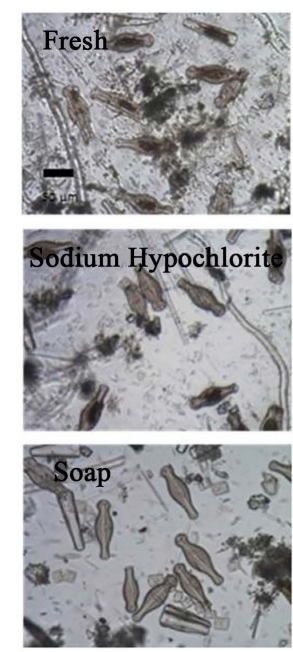

(a)

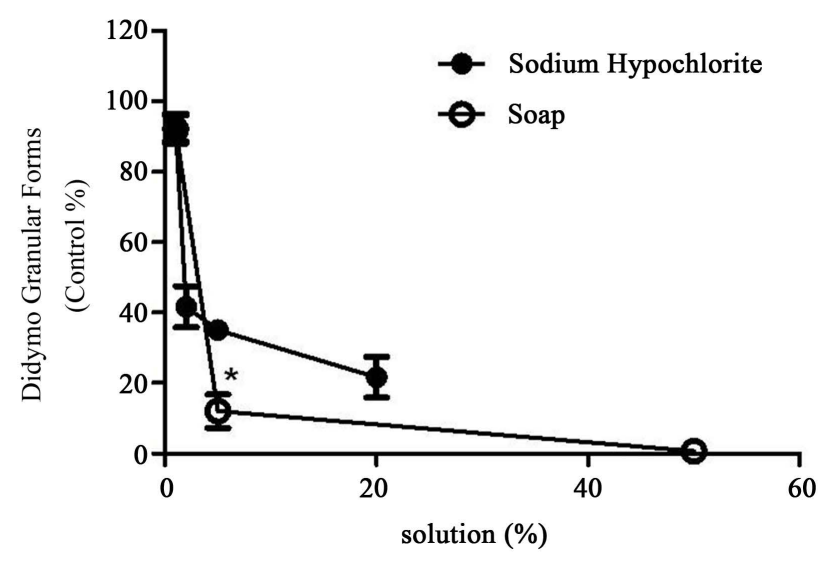

(b)

Figure 5. Comparative effects of detergent and sodium hypochlorite. (a) Photomicrographs of D. geminata under different conditions; (b) Graph of increasing concentrations for sodium hypochlorite and soap. Photomicrographs are representative of 5 independent experiments. Each point represents (mean \pm SEM) the measurement of at least 5 independent experiments. The asterisk indicates $p<0.05$ (ANOVA).

is shown in the literature, we have shown it is possible to study them in vitro. This study confirms that $D$. geminata can be maintained in the laboratory (Figure 1(c) and Figure 2(a)) using the protocols previously described in the methods section to keep them fresh, and achieving a viability of about $90 \%$ for several months. We used these methods for the fresh sample in our experiments (Figure 3 and Figure 4). Thus, it seems possible to have a handling system for viable $D$. geminata in the laboratory using the protocol described above. This method can be improved to include river conditions, since the level of dissolved nutrients water has been described as favoring the growth of microalgae, but altering them would disturb the natural flora of rivers [20].

Many authors note that drying the samples of $D$. geminata would be a good way to control this pest [7], and it is widely used in various countries, including Chile. However, our findings suggest that while the method reduces the viability of the samples (Figure 1 (d)), mortality only reaches about $50 \%$. Mortality increases to $80 \%$ when the samples were subjected to constant temperatures of $38^{\circ} \mathrm{C}$ for 4 weeks (Figure 1 (d)), an environment clearly not replicable in natural conditions, therefore requiring review of the procedure. In Chile, humid conditions would support the preservation of $D$. geminata when drying naturally; this idea is reinforced with our research, since only when using an oven-drying model (a closed system at a constant temperature) did we achieve a faster, and significant increase in sample mortality (Figure 1(d)). Taking this into consideration, dry D. geminata obtained from the rock of the rivers sampled was used, rehydrating them to assess their viability. We found that only $40 \%$ of the samples were viable, a value similar to that found in the samples maintained in aquariums (Figure 2(b)). The naturally dried samples retain a high viability; therefore they cannot be used as a single control method. Subjecting the "didymo" to a constant high temperature $\left(38^{\circ} \mathrm{C}\right)$ show that it can be controlled, but this method requires other implementations and precautions. Other biosafety protocols are described as suitable for controlling D. geminata [20]-[22], such as the use of $\mathrm{NaCl}$ solutions [21]. The effect of increasing $\mathrm{NaCl}$ concentrations on D. geminata viability was evaluated (Figure 3(b)), showing that $25 \%$ solutions for 30 minutes achieved a $D$. geminata cell mortality of more than $80 \%$ (Figure $3(b)$ ). A $10 \% \mathrm{NaCl}$ solution was successful in reducing the viability by $50 \%$ after 30 min of incubation, and when used for longer the effect increased reaching values of $80 \%$ mortality (Figure 3(c)). It is suggested that the use of $\mathrm{NaCl}$ is a good way to control D. geminata; however, it leaves an important margin of viable forms, requiring an incubation time and $\mathrm{NaCl}$ concentration greater than what is recommended in research literature [21]. Our experiments show that using soap solution ( $5 \%$ soap for $5 \mathrm{~min}$ ) reduces viability of $D$. geminata cells by more than $90 \%$ (Figure 4(b)), achieving values similar to those observed with acid digestion. This is an easy way to reduce $D$. geminata cell viability in a short period of time, and can be directly implemented to clean areas, equipment, and to ensure the low dispersion of samples being worked on in the laboratory. Additionally, we compared the effects of soap so- 
lution and sodium hypochlorite in controlling “didymo”, finding that both treatments have significant effects on viability. However, the treatment with a $10 \%$ soap solution was more efficient (10\% viability) than the $10 \%$ sodium hypochlorite solution (20\% viability), and solutions with higher concentrations of soap were nearly $100 \%$ effective. Treatment with soap solution is a much more effective and inexpensive control for D. geminata (Figure 5).

\section{Conclusion}

Our findings show that it is possible to safely grow D. geminata under laboratory conditions, opening lines of research for better studying the biology and development of these microalgae. Our results indicate that the use of $5 \%$ soap solutions for $5 \mathrm{~min}$ is efficient in removing over $90 \%$ of the viable forms of $\mathrm{D}$. geminata. Finally, dry samples of $D$. geminata are only efficient when they are induced at temperatures of at least $38^{\circ} \mathrm{C}$ for several weeks, suggesting that the drying implemented as a control mechanism up until now is not a good barrier to prevent the spread of “didymo" in rivers systems.

\section{Acknowledgements}

Funded by, the UCT Technical Assistance Agreement 278-2472 Didy 2013. Jorge Parodi has MECESUP UCT 0804 funding. We are indebted to Professor Ian Scott for his translation, revision and editing. Language editing services were provided by www.journalrevisions.com. We would like to thank Ms. Díaz, for the supply of fresh microalgae material.

\section{References}

[1] Rivera, P., Basualto, S. and Cruces, F. (2013) On the Diatom Didymosphenia geminata (Lyngbye) M. Schmidt: Its Morphology and Distribution in Chile. Gayana Botanica, 70, 154-158. http://dx.doi.org/10.4067/S0717-66432013000100015

[2] Kelly, M.G. (2003) Short Term Dynamics of Diatoms in an Upland Stream and Implications for Monitoring Eutrophication. Environmental Pollution, 125, 117-122. http://dx.doi.org/10.1016/S0269-7491(03)00075-7

[3] Stoermer, E.F., Kreis Jr., R.G. and Andresen, N.A. (1999) Checklist of Diatoms from the Laurentian Great Lakes. II. Journal of Great Lakes Research, 25, 515-566. http://dx.doi.org/10.1016/S0380-1330(99)70759-8

[4] Reid, B.L., Hernandez, K.L., Frangopulos, M., Bauer, G., Lorca, M., Kilroy, C. and Spaulding, S. (2012) The Invasion of the Freshwater Diatom Didymosphenia geminata in Patagonia: Prospects, Strategies, and Implications for Biosecurity of Invasive Microorganisms in Continental Waters. Conservation Letters, 5, 432-440.

http://dx.doi.org/10.1111/j.1755-263X.2012.00264.x

[5] Beville, S.T., Kerr, G.N. and Hughey, K.F.D. (2012) Valuing Impacts of the Invasive Alga Didymosphenia geminata on Recreational Angling. Ecological Economics, 82, 1-10. http://dx.doi.org/10.1016/j.ecolecon.2012.08.004

[6] Bothwell, M.L. and Kilroy, C. (2011) Phosphorus Limitation of the Freshwater Benthic Diatom Didymosphenia geminata Determined by the Frequency of Dividing Cells. Freshwater Biology, 56, 565-578. http://dx.doi.org/10.1111/j.1365-2427.2010.02524.X

[7] Clearwater, S.J., Jellyman, P.G., Biggs, B.J.F., Hickey, C.W., Blair, N. and Clayton, J.S. (2011) Pulse-Dose Application of Chelated Copper to a River for Didymosphenia geminata Control Effects on Macroinvertebrates and Fish. Environmental Toxicology and Chemistry, 30, 181-195. http://dx.doi.org/10.1002/etc.369

[8] Jellyman, P.G., Clearwater, S.J., Clayton, J.S., Kilroy, C., Blair, N., Hickey, C.W. and Biggs, B.J.F. (2011) Controlling the Invasive Diatom Didymosphenia geminata: An Ecotoxicity Assessment of Four Potential Biocides. Archives of Environmental Contamination and Toxicology, 61, 115-127. http://dx.doi.org/10.1007/s00244-010-9589-z

[9] Clearwater, S.J., Jellyman, P.G., Biggs, B.J., Hickey, C.W., Blair, N. and Clayton, J.S. (2010) Pulse-Dose Application of Chelated Copper to a River for Didymosphenia geminata Control: Effects on Macroinvertebrates and Fish. Environmental Toxicology and Chemistry, 30, 181-195. http://dx.doi.org/10.1002/etc.369

[10] Kilroy, C., Larned, S.T. and Biggs, B.J.F. (2009) The Non-Indigenous Diatom Didymosphenia geminata Alters Benthic Communities in New Zealand Rivers. Freshwater Biology, 54, 1990-2002. http://dx.doi.org/10.1111/j.1365-2427.2009.02247.x

[11] Bergey, E.A., Cooper, J.T. and Phillips, B.C. (2010) Substrate Characteristics Affect Colonization by the Bloom-Forming Diatom Didymosphenia geminata. Aquatic Ecology, 44, 33-40. http://dx.doi.org/10.1007/s10452-009-9247-6

[12] Gillis, C.A. and Chalifour, M. (2010) Changes in the Macrobenthic Community Structure Following the Introduction 
of the Invasive Algae Didymosphenia geminata in the Matapedia River (Québec, Canada). Hydrobiologia, 647, 63-70.

[13] Olivares, P., Orellana, P., Guerra, G., Peredo-Parada, M., Chavez, V., Ramirez, A. and Parodi, J. (2015) Water Contaminated with Didymosphenia geminata Generates Changes in Salmo salar Spermatozoa Activation Times. Aquatic Toxicology, 163, 102-108. http://dx.doi.org/10.1016/j.aquatox.2015.03.022

[14] Crippen, R.W. and Perrier, J.L. (1974) The Use of Neutral Red and Evans Blue for Live-Dead Determinations of Marine Plankton (with Comments on the Use of Rotenone for Inhibition of Grazing). Stain Technology, 49, 97-104. http://dx.doi.org/10.3109/10520297409116949

[15] Jellyman, P.G., Clearwater, S.J., Clayton, J.S., Kilroy, C., Hickey, C.W., Blair, N. and Biggs, B.J.F. (2010) Rapid Screening of Multiple Compounds for Control of the Invasive Diatom Didymosphenia geminata. Journal of Aquatic Plant Management, 48, 63-71.

[16] Bothwell, M.L., Taylor, B.W. and Kilroy, C. (2014) The Didymo Story: The Role of Low Dissolved Phosphorus in the Formation of Didymosphenia geminata Blooms. Diatom Research, 29, 229-236. http://dx.doi.org/10.1080/0269249X.2014.889041

[17] Kuhajek, J.M., Lemoine, M., Kilroy, C., Cary, S.C., Gerbeaux, P. and Wood, S.A. (2014) Laboratory Study of the Survival and Attachment of Didymosphenia geminata (Bacillariophyceae) in Water Sourced from Rivers throughout New Zealand. Phycologia, 53, 1-9. http://dx.doi.org/10.2216/13-145.1

[18] Agrawal, S.C. and Singh, V. (2002) Viability of Dried Filaments, Survivability and Reproduction under Water Stress, and Survivability Following Heat and UV Exposure in Lyngbya martensiana, Oscillatoria agardhii, Nostoc calcicola, Hormidium fluitans, Spirogyra sp. and Vaucheria geminata. Folia Microbiologica, 47, 61-67. http://dx.doi.org/10.1007/BF02818567

[19] Aboal, M., Marco, S., Chaves, E., Mulero, I. and Garcia-Ayala, A. (2012) Ultrastructure and Function of Stalks of the Diatom Didymosphenia geminata. Hydrobiologia, 695, 17-24. http://dx.doi.org/10.1007/s10750-012-1193-y

[20] Kilroy, C. and Bothwell, M. (2011) Environmental Control of Stalk Length in the Bloom-Forming, Freshwater Benthic Diatom Didymosphenia geminata (Bacillariophyceae). Journal of Phycology, 47, 981-989. http://dx.doi.org/10.1111/j.1529-8817.2011.01029.x

[21] Root, S. and O’Reilly, C.M. (2012) Control: Increasing the Effectiveness of Decontamination Strategies and Reducing Spread. Fisheries, 37, 440-448. http://dx.doi.org/10.1080/03632415.2012.722873

[22] Domozych, D.S., Toso, M. and Snyder, A. (2010) Biofilm Dynamics of the Nuisance Diatom, Didymosphenia geminata (Bacillariophyceae). Nova Hedwigia, 136, 249-259. 